\title{
Structural complexity at and around the Triassic-Jurassic GSSP at Kuhjoch, Northern Calcareous Alps, Austria
}

\author{
M. Palotai ${ }^{1,2} \cdot$ J. Pálfy ${ }^{1,3} \cdot$ Á. Sasvári ${ }^{4}$
}

Received: 16 February 2016 / Accepted: 24 January 2017

(C) The Author(s) 2017. This article is published with open access at Springerlink.com

\begin{abstract}
One of the key requirements for a Global Stratotype Section and Point (GSSP) is the absence of tectonic disturbance. The GSSP for the Triassic-Jurassic system boundary was recently defined at Kuhjoch, Northern Calcareous Alps, Austria. New field observations in the area of the Triassic-Jurassic boundary GSSP site demonstrate that the overturned, tight, and almost upright Karwendel syncline was formed at semibrittle deformation conditions, confirmed by axial planar foliation. Tight to isoclinal folds at various scales were related to a tectonic transport to the north. Brittle faulting occurred before and after folding as confirmed by tilt tests (the rotation of structural data by the average bedding). Foliation is ubiquitous in the incompetent units, including the Kendlbach Formation at the GSSP. A reverse fault (inferred to be formed as a normal fault before folding) crosscuts the GSSP sections, results in the partial tectonic omission of the Schattwald Beds, and thus makes it impossible to measure a complete and continuous stratigraphic section across the whole Kendlbach Formation. Based on these observations, the Kuhjoch sections do not fulfil the specific requirement for a GSSP regarding the absence of tectonic disturbances near boundary level.
\end{abstract}

Electronic supplementary material The online version of this article (doi:10.1007/s00531-017-1450-4) contains supplementary material, which is available to authorised users.

\section{Palotai}

marton.palotai@casp.cam.ac.uk

1 Department of Geology, Eötvös Loránd University, Pázmány Péter sétány 1/C, Budapest 1117, Hungary

2 CASP, 181A Huntingdon Road, Cambridge CB3 0DH, UK

3 MTA-MTM-ELTE Research Group for Paleontology, Pázmány Péter sétány 1/C, Budapest 1117, Hungary

4 Llandudno, Gwynedd LL30 1SA, UK
Keywords GSSP $\cdot$ Jurassic $\cdot$ Triassic $\cdot$ Kuhjoch . Faulting $\cdot$ Folding

\section{Introduction}

Modern chronostratigraphy is underpinned by the Global Stratotype Section and Point (GSSP) concept, whereby the lower boundary of each chronostratigraphic unit is defined at a certain level in the best available stratigraphic section for the investigated interval, as agreed by the regulating bodies of the international stratigraphic community (Remane 2003). The base of the Jurassic System was recently defined at Kuhjoch in the Northern Calcareous Alps of Austria (Hillebrandt et al. 2013). The Kuhjoch GSSP is claimed to be the best continuous, non-condensed section of sedimentary rocks of latest Triassic and earliest Jurassic age worldwide (Hillebrandt et al. 2013; Morton 2012). Although many stratigraphical, paleontological and geochemical aspects related to the GSSP have already been covered (Hillebrandt et al. 2013), no detailed structural geological study has been carried out to clarify the deformation history of the site and its broader area. Detailed, 1:10 000 scale mapping of the area was completed in the 1970s and remained unpublished (Schütz 1974).

To provide a better understanding of the regional geological context, deformation history and conditions as well as local structural geological phenomena of the GSSP, the authors investigated and interpreted an extended geological profile across the site. This exercise also enabled us to test the repeatedly expressed assumption that the GSSP section is free of structural complexities that would limit its use as a stratigraphic standard (Hillebrandt et al. 2007, 2013). 


\section{Geological setting}

The Kuhjoch GSSP (Hillebrandt et al. 2013) is located on the overturned southern limb of the Karwendel syncline (Eisbacher and Brandner 1996) (Fig. 1). The Karwendel syncline forms a Paleogene fault propagation fold (Tanner et al. 2003) in the Lechtal nappe, which in turn is part of the upper Bavaric unit (or nappe system) in the western Northern Calcareous Alps (Tollmann 1976b). Deformation is constrained to anchimetamorphic conditions as a maximum (less than $200^{\circ} \mathrm{C}$ ) as defined by illite crystallinity data (Kralik et al. 1987). The maximum temperature is inferred to have not exceeded $50{ }^{\circ} \mathrm{C}$ based on local palynomorph and conodont (CAI, Conodont Alteration Index $=1$ ) preservation (Hillebrandt et al. 2013; Kuerschner et al. 2007). Regionally, similar CAI values of 1 in the Tirolic units of the central Northern Calcareous Alps are thought to correspond to temperature ranges of $50-80^{\circ} \mathrm{C}$ (Gawlick et al. 1994), whereas palynomorph preservation from another locality in the Eiberg basin suggest a maximum of $65^{\circ} \mathrm{C}$ (Kuerschner et al. 2007).

The local stratigraphy around the Kuhjoch section is summarised below on the basis of a detailed $(1: 10,000$ scale) unpublished map of Schütz (1974) and the recently compiled 1:50,000 scale map of Moser (2008), with further details of the Triassic-Jurassic boundary strata provided by Hillebrandt et al. (2013), Richoz and Krystyn (2015) and Mette et al. (2016) (Fig. 2). The overall stratigraphic architecture of the Karwendel syncline and more broadly the Bavaric unit is complex and not free of controversies. Our stratigraphic summary follows the views of Gawlick et al. (2009), which partly contradicts the widely used chart of Piller and Erhart (2004), albeit both are built on the stratigraphic synthesis of the Northern Calcareous Alps by Tollmann (1976a). Paleogeographic reconstructions suggest that Triassic-Jurassic boundary strata were deposited in the Eiberg basin, a large, elongated intraplatform basin developed in the latest Triassic on the passive margin of

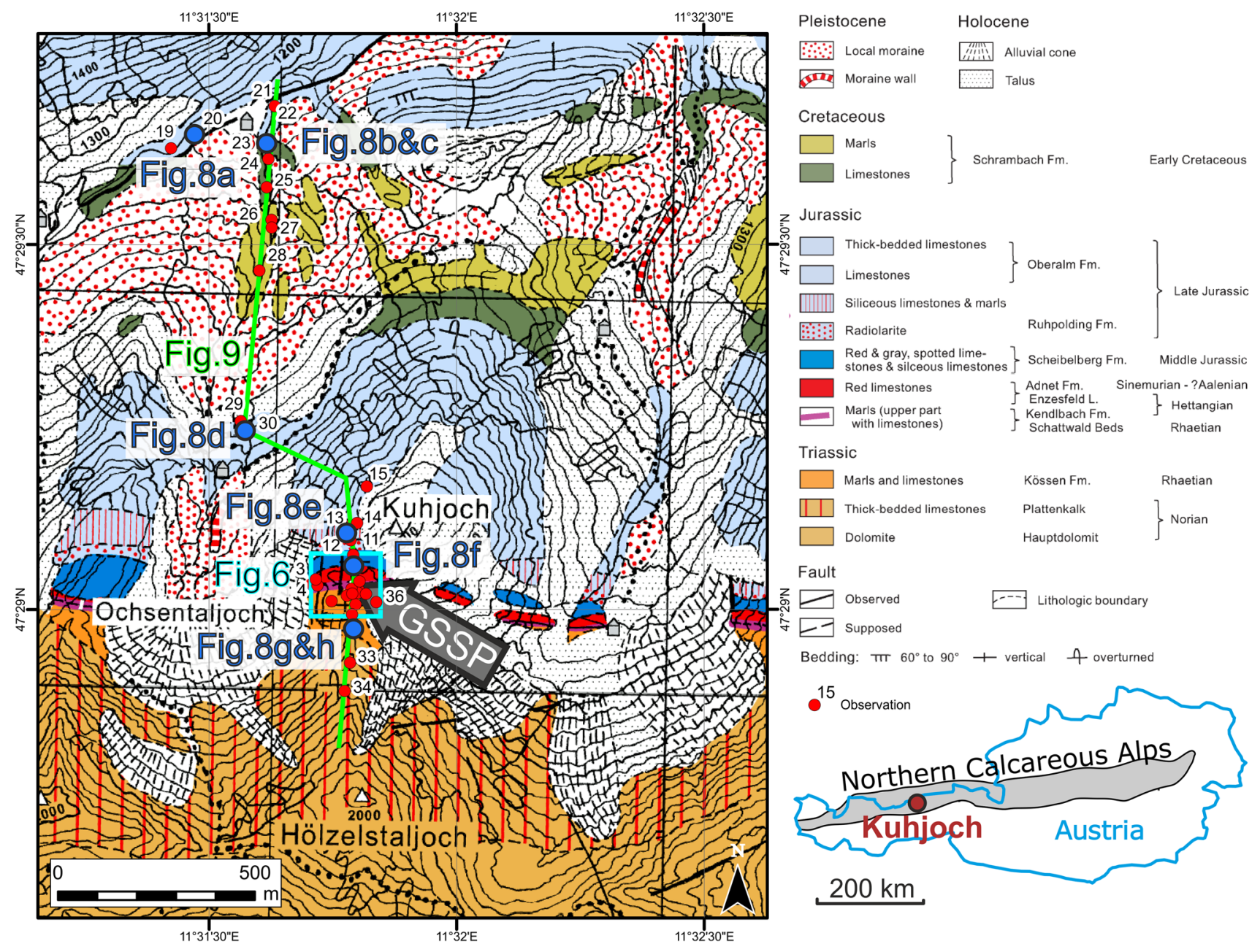

Fig. 1 Location of Kuhjoch in the Northern Calcareous Alps and geological map of the surroundings of Kuhjoch [modified after Schütz (1974) in Hillebrandt et al. (2013)] 
Fig. 2 Upper Triassic-Lower Cretaceous stratigraphy of the Karwendel syncline (a), and the stratigraphic section of Kuhjoch (b) [modified after Hillebrandt et al. (2013), Gawlick et al. (2009), Schütz (1974) and Krische et al. (2013)]. An arrow pair indicates the position of the Triassic-Jurassic boundary according to Hillebrandt et al. (2013)

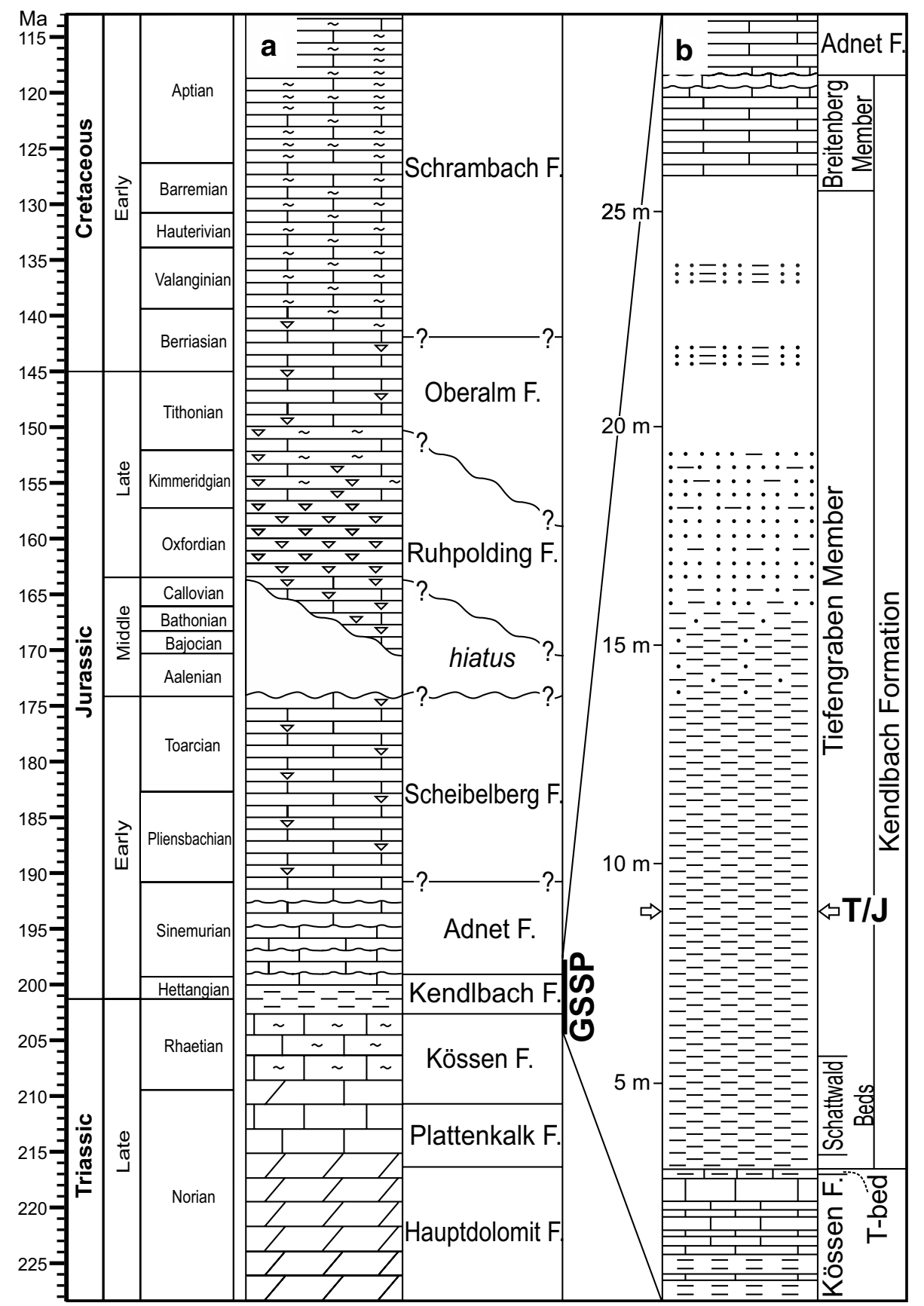

Neotethys, which separated the Dachstein carbonate platform from the more northerly located rimmed platform attached to the European continental foreland (Krystyn et al. 2005). Stratigraphic relationships and facies patterns were disrupted during successive phases of Alpine deformation (Linzer et al. 1995).

The Norian stage is represented by the Hauptdolomit and Plattenkalk formations. The Hauptdolomit comprises thick-bedded dolostones deposited in a lagoon of an extensive carbonate platform. The transition to the Plattenkalk is gradational, and the latter formation comprises grey limestones with characteristic platy bedding, and occasional dolomitic intervals and thin marl interbeds (Schütz 1974).

The uppermost Norian-Rhaetian Kössen Formation develops gradually from the underlying Plattenkalk by an increase of clay, pyrite and organic matter content, indicating deepening of the basin. The Kössen Formation comprises dark limestones and marls, whereas its uppermost 20 -cm-thick bed (the so-called T-bed) is characterised by dark colour, increased clay and organic content and platy weathering, suggesting anoxic conditions (Hillebrandt et al. 
2007). The uppermost ca. 2 m of the Kössen Formation are the oldest strata exposed in the Kuhjoch GSSP trenches.

The Kössen Formation is overlain with an abrupt lithological change by the uppermost Rhaetian-lowermost Hettangian Tiefengraben Member of the Kendlbach Formation. This succession starts with the Schattwald Beds, a succession of grey to brown clay-rich marls that are overlain by yellow laminated marls and red, partly laminated silty clays, recording an increase of terrigenous influx. Hillebrandt et al. (2013) report a thickness of $2.8 \mathrm{~m}$ for this unit in the Kuhjoch East section and ca. $2 \mathrm{~m}$ at Kuhjoch West, where tectonic omission in the latter section is apparent from the lack of a palynomorph assemblage zone and a sudden shift in the $\delta^{13} \mathrm{C}$ curve. Natural outcrops of this recessive unit are rare, and where observed, it is commonly tectonised, e.g. faulted at both the nearby Hochalplgraben section and in the Eiberg quarry (Hillebrandt et al. 2013). Its true thickness is, therefore, difficult to determine: according to Gawlick et al. (2009), it is typically 1-3 m but locally may reach up to $7 \mathrm{~m}$, whereas Furrer (1993) reports common thickness values of 6-10 $\mathrm{m}$ in the western Lechtal nappe. The greatest known thickness measured during construction of a tunnel in the Allgäu nappe is ca. $50 \mathrm{~m}$, although it may be tectonically inflated (Köhler 1986).

The Schattwald Beds grade into the overlying main part of the Tiefengraben Member that becomes siltier and finely arenitic upwards. The Golden Spike (Fig. 3a) that marks the base of the Jurassic system is placed at the first occurrence of Psiloceras spelae tirolicum within the Tiefengraben Member at Kuhjoch (Hillebrandt et al. 2013). The Tiefengraben Member is overlain by the grey thin-bedded limestones of the Breitenberg Member of the Kendlbach Formation. The Breitenberg Member also includes marl beds, condensed horizons and hardground levels (Hillebrandt et al. 2007). The GSSP trenches expose the succession up to the base of the Adnet Formation which comprises platy to nodular red limestones of pelagic origin and here yielded middle and late Hettangian ammonites (Hillebrandt et al. 2013).

The age of the top of the Adnet Formation is poorly constrained; north of the artificial exposure it yielded Sinemurian ammonites and is overlain by red and grey, spotted limestones and siliceous limestones of the Scheibelberg Formation which is known to range up to the Toarcian elsewhere (Gawlick et al. 2009). After a gap of poorly constrained duration, deep basinal sedimentation resumed as evidenced by the Middle to Upper Jurassic radiolarites, siliceous limestones and marls of the Ruhpolding Formation, and the overlying, partly siliceous limestones of the Upper Jurassic to lowermost Cretaceous Oberalm Formation (Hillebrandt et al. 2013; Schütz 1974). Upwards there is gradual transition to the dark, marly limestones of the aptychus-bearing Lower Cretaceous Schrambach
Formation, whose oldest age is established elsewhere as mid-Berriasian (Krische et al. 2013). Its upper part is dominated by marls, representing the youngest unit encountered in our tectonically oriented field survey in the vicinity of the Kuhjoch section.

\section{Structural observations at the GSSP site}

The Global Stratotype Section consists of two subparallel artificial trenches on both sides of the Kuhjoch pass, referred to as sections Kuhjoch West and East (Fig. 3). The proposal prepared for the official ballot by the Triassic-Jurassic Boundary Working Group of the International Subcommission on Jurassic Stratigraphy, and eventually by the International Commission on Stratigraphy, presented Kuhjoch West as the GSSP candidate (Hillebrandt et al. 2007). However, after the vote in favour of the Kuhjoch site, the Global Stratotype Section and Point (the 'Golden Spike') was eventually defined in the subsequently excavated Kuhjoch East section (Fig. 3) (Hillebrandt et al. 2013).

Structural measurements at the GSSP sections and in the Karwendel syncline are found in Online Resource 1.

The beds dip to the south at the GSSP sections. Observations on bedding geometry are difficult within the Tiefengraben Member due to its lithological homogeneity. Two intersecting surface sets were identified (Fig. 4a, b), but a direct and unambiguous distinction of bedding and foliation could not be established. Following the general consideration of the relative dip angle of bedding and foliation in overturned folds (Fig. 4c) and accepting the overturned fold geometry confirmed by data of Schütz (1974) and our regional findings ("Structural observations in the Karwendel syncline"), the steeper plane set was tentatively established to be the bedding, the shallow dipping features were accepted as foliation (Fig. 4a, b).

In both the eastern and the western trenches, the contact between the Kössen limestone and the Tiefengraben Member is tectonic: a steep, roughly east-west striking fault separates these formations (Figs. 3, 5, 6, 7g). This phenomenon has only been partly noticed previously (Hillebrandt et al. 2013). The fault, striking perpendicular to the trenches, is exposed at subsections $2 \mathrm{D}$ and $2 \mathrm{E}$ of Hillebrandt et al. (2013), too (Fig. 3a). During our field work, in subsection $2 \mathrm{E}$, the T-Bed was exposed in the footwall, and the Schattwald Beds were inferred in the scree (Fig. 5b). Bedding and/or foliation planes in the Schattwald Beds were only observed in the hanging wall. In subsection 2D, even the T-Bed was buried in the footwall position, and the fault juxtaposed the Kössen Formation in the footwall to the Schattwald Beds in the hanging wall. The continuation of the same east-west striking 

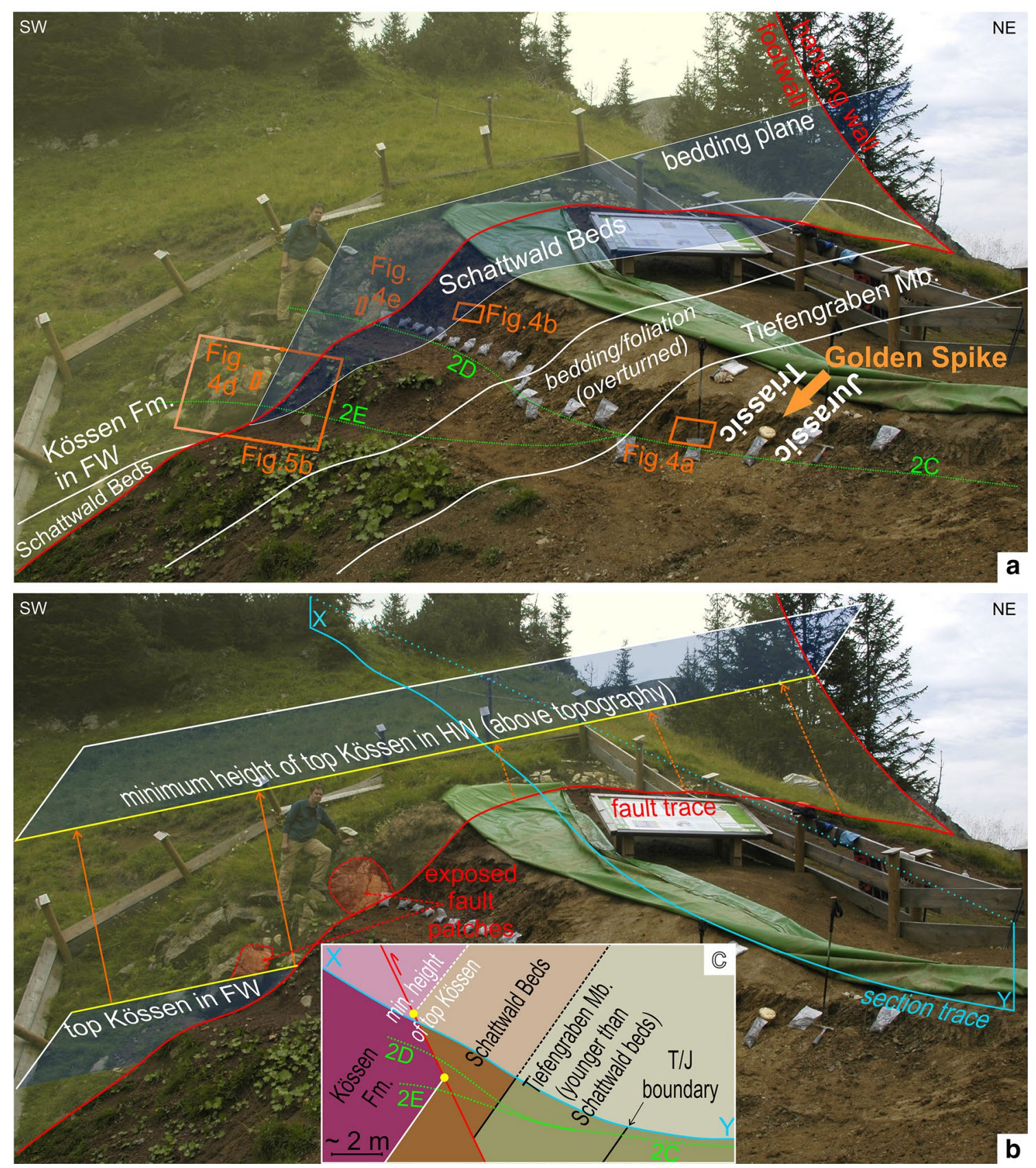

Fig. 3 Structural interpretation of the Kuhjoch East section. Note that all formations are overturned. Photograph courtesy of N. Zajzon. Second author for scale. a Overview of the outcrop. The bedding and/or foliation in the Tiefengraben Member is steep, indicated by a semitransparent blue plane and white lines for the intersection with the topography. The Golden Spike of the Triassic-Jurassic boundary is positioned within the Tiefengraben Member. The Kössen Formation and the Tiefengraben Member are separated by a reverse fault dipping towards the observer (semitransparent with red outline). $2 \mathrm{C}$, $2 \mathrm{D}$ and $2 \mathrm{E}$ in green refer to subsections according to Fig. 8 of Hillebrandt et al. (2013). $F W$ footwall, $H W$ hanging wall. b Offset along the reverse fault. The two semitransparent blue horizons with white outlines are (1) the top Kössen Formation cropping out in the footwall and (2) the minimal height of the top Kössen Formation in the hanging wall above the topography, respectively. Any higher position of this latter horizon might be valid, but lower positions can be ruled out as the Kössen Formation is absent in outcrop in the hanging wall. The intersection lines of the top Kössen Formation with the reverse fault are shown as yellow lines. The distance between the two yellow lines indicates the minimum offset along the fault. The exposed segments of the fault are shown in semitransparent red. The section trace of inset $\mathbf{c}$ is shown in blue. $\mathbf{c}$ Schematic cross section of the Kuhjoch East site along the highest part of the Kuhjoch saddle. The Kössen Formation is inferred above the topography in the hanging wall. Yellow dots mark the two intersection points of the intersection lines of the reverse fault and the top Kössen Formation in the footwall and the hanging wall, respectively, with the cross-sectional plane. The exposed succession of the Schattwald Beds in subsection 2E of Hillebrandt et al. (2013) (shown in green; location shown on a) is crosscut by the reverse fault, while in subsection $2 \mathrm{D}$ the fault juxtaposes the Kössen Formation in the footwall to the Schattwald Beds in the hanging wall 

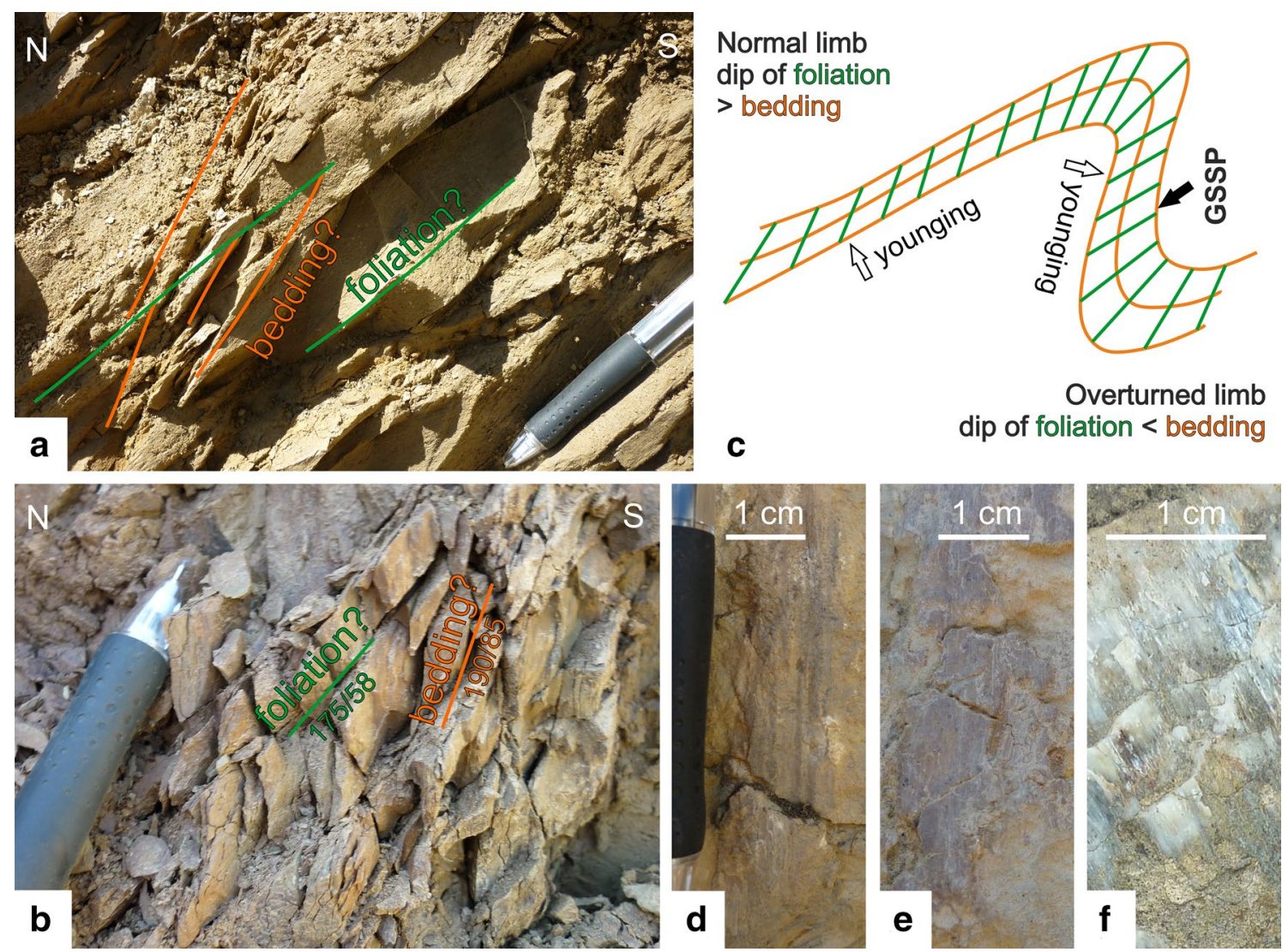

Fig. 4 a, b Bedding/foliation relationships inferred at Kuhjoch East. Locations are shown in Fig. 3a. c General geometry of bedding and syn-folding foliation on normal and overturned fold limbs. d-f Kin- ematic indicators on the GSSP fault. d Assumed reverse striations. e Striated clay on the fault surface. Location in Fig. 3a. f Certain reverse slickensides about $15 \mathrm{~m}$ from the GSSP. Location in Fig. 6
Fig. 5 Boundary fault between the Kössen limestone and the Schattwald Beds in the Kuhjoch West (a) and East (b) sections. All formations are overturned. In the eastern section, the absence of Schattwald Beds stratigraphically above (but topographically below) the T-Bed in the footwall is due to bad outcrop conditions. Note the overall insufficient exposure of the Schattwald Beds, making the bedding definition of this formation difficult. For location see Figs. $3 \mathrm{a}$ and 6
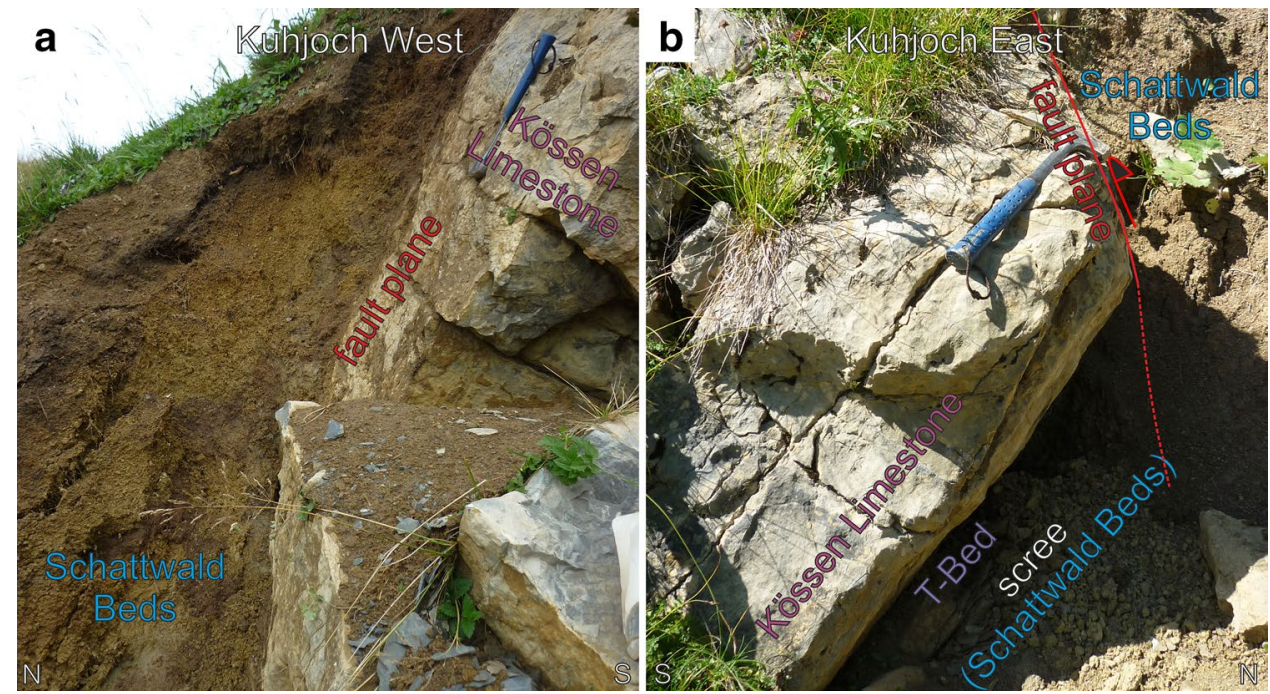

fault was identified about $15 \mathrm{~m}$ to the east of the Kuhjoch East section in a natural outcrop (indexed 'Fig. $4 \mathrm{f}$ ' in Fig. 6), where the contact of the Kössen and Kendlbach formations was faulted again.
In the Kuhjoch West section, the same steep fault setting was detected (Fig. 5a), with the measured directions slightly deviating relative to the eastern trench (Fig. 6). In the footwall, a continuous succession from the Kössen 


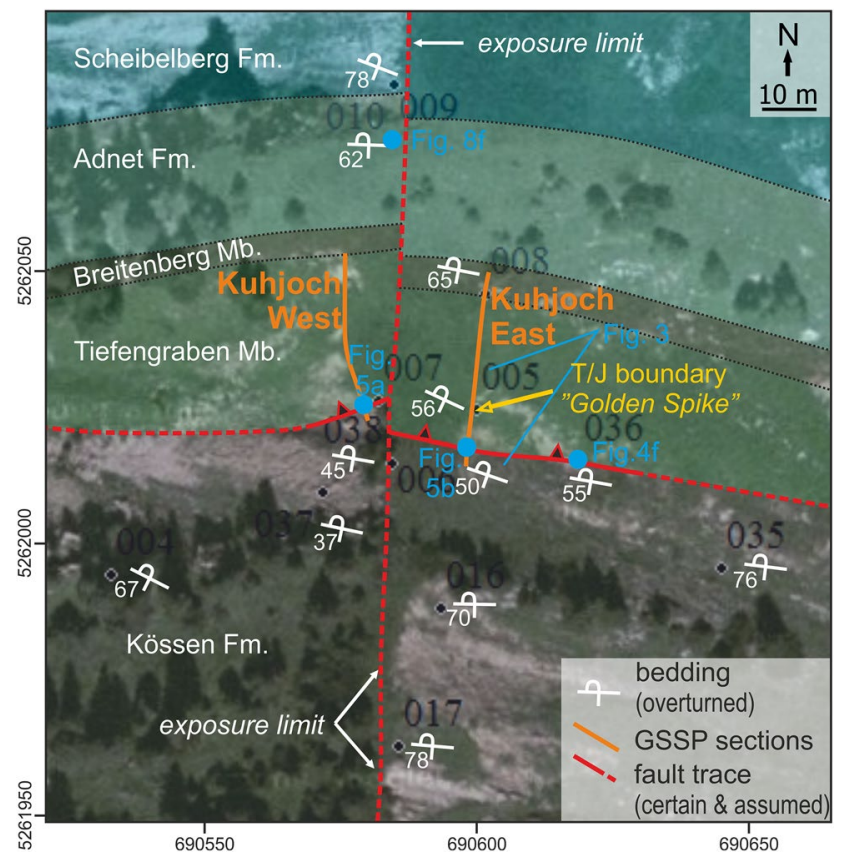

Fig. 6 Geological map of the vicinity of the GSSP. Note the limits of natural outcrops delineating the north-south trending fault. Base map: Google

Formation to the base of the Schattwald Beds was excavated. In the hanging wall, the Schattwald Beds were identified as well, but, as the fault runs in between, no complete section of the Schattwald Beds could be established.

The fault trace is offset between the eastern and western sections. As identified in the field and evident from the termination of outcrops in the landscape (Fig. 6), a north-south striking structure with a small apparent dextral offset separates the eastern and eastern sections. Unfortunately, the few observed faults planes in the area in the north-south direction host oblique lineations (Fig. 7d), making the interpretation of fault kinematics difficult.

Fault striations and slickensides indicate reverse kinematics on the east-west striking fault at the GSSP in all studied locations (Fig. 7g). Indications for this reverse fault setting are best exposed at the natural outcrop about $15 \mathrm{~m}$ to the east of the Kuhjoch East section (Fig. 4f), and are likely in both the Kuhjoch East (Fig. 4d, e) and West trenches. A few strike-slip striae were also observed (Fig. 7g); however, the superposition of the reverse and strike-slip phases could not be established.

As the bedding planes of the Kössen Formation and the fault plane both strike approximately east-west (Fig. 6), their intersection lines are subhorizontal (Fig. 3b). In the hanging wall, the intersection line between the reverse fault and the top of the Kössen Formation needs to be inferred above the topography (Fig. 3b, c). This assumption is justified because the Kössen Formation does not crop out in the hanging wall position in the Kuhjoch saddle, not even along the highest part of the saddle (Fig. 3b, c). Lower hanging wall positions of the top Kössen Formation, than that shown in Fig. 3b, c, can therefore be ruled out. However, any higher position of the top Kössen horizon in the hanging wall might be valid. The calculated minimum reverse offset along the fault is, therefore, $2-3 \mathrm{~m}$ (Fig. 3b, c). The actual offset is not believed to be much larger than that, requiring only a slight, but locally important modification of the excellent map of Schütz (1974) (Figs. 1, 6).

The exposed thickness of the Schattwald Beds is ca. $2 \mathrm{~m}$ in the Kuhjoch trenches (Fig. 3) (cf. Hillebrandt et al. 2013). As shown in Fig. 3c, this is a combined thickness of faulted Schattwald strata in the footwall and in the hanging wall in subsection $2 \mathrm{E}$ and, therefore, does not represent a continuous stratigraphic succession. In subsection $2 \mathrm{D}$, the base of the Schattwald Beds is missing due to offset along the fault (Fig. 3c).

Accepting the 2-3 m minimum reverse offset, the true stratigraphic thickness of the Schattwald Beds is inferred to be 4-5 $\mathrm{m}$, well within the range of thickness variation of this unit supported by regional stratigraphic data (Furrer 1993; Gawlick et al. 2009). The geometry of the fault relative to bedding implies that, at least at Kuhjoch East where more detailed structural observations were undertaken, the basal part of the Schattwald Beds is missing in outcrop (Fig. 3c). Any increase of offset would imply further increase in Schattwald thickness.

\section{Structural observations in the Karwendel syncline}

To have a good understanding of the geology around the GSSP, a geological cross section (Fig. 9) was constructed from the outcrops (Fig. 8) in the valley below, and on the ridge above Kuhjoch Pass (Fig. 1). Dip data (Fig. 7a) were projected along strike onto the section. Outcrop scale folds are only shown as surface observations on the section, but not visualised as parasitic folds of the large-scale structure. The general structural architecture is simple: a steep, overturned, almost isoclinal syncline was identified (Fig. 9), in good agreement with earlier observations on the Karwendel syncline (Eisbacher and Brandner 1996; Linzer et al. 1995; Tanner et al. 2003), although the tight character of the fold has not been emphasised before.

At the northern part of the transect (on the normal limb of the syncline, see Fig. 9), the exposed Upper Jurassic and Cretaceous formations are intensely folded into outcrop scale asymmetric upright isoclinal folds (Fig. 8a). Rocks at the normal limb (northern part of the transect) seem to be more deformed than in the south. East-west-oriented fold axis directions (Figs. 7e, 8c) indicate north-south shortening. Wherever it could be 

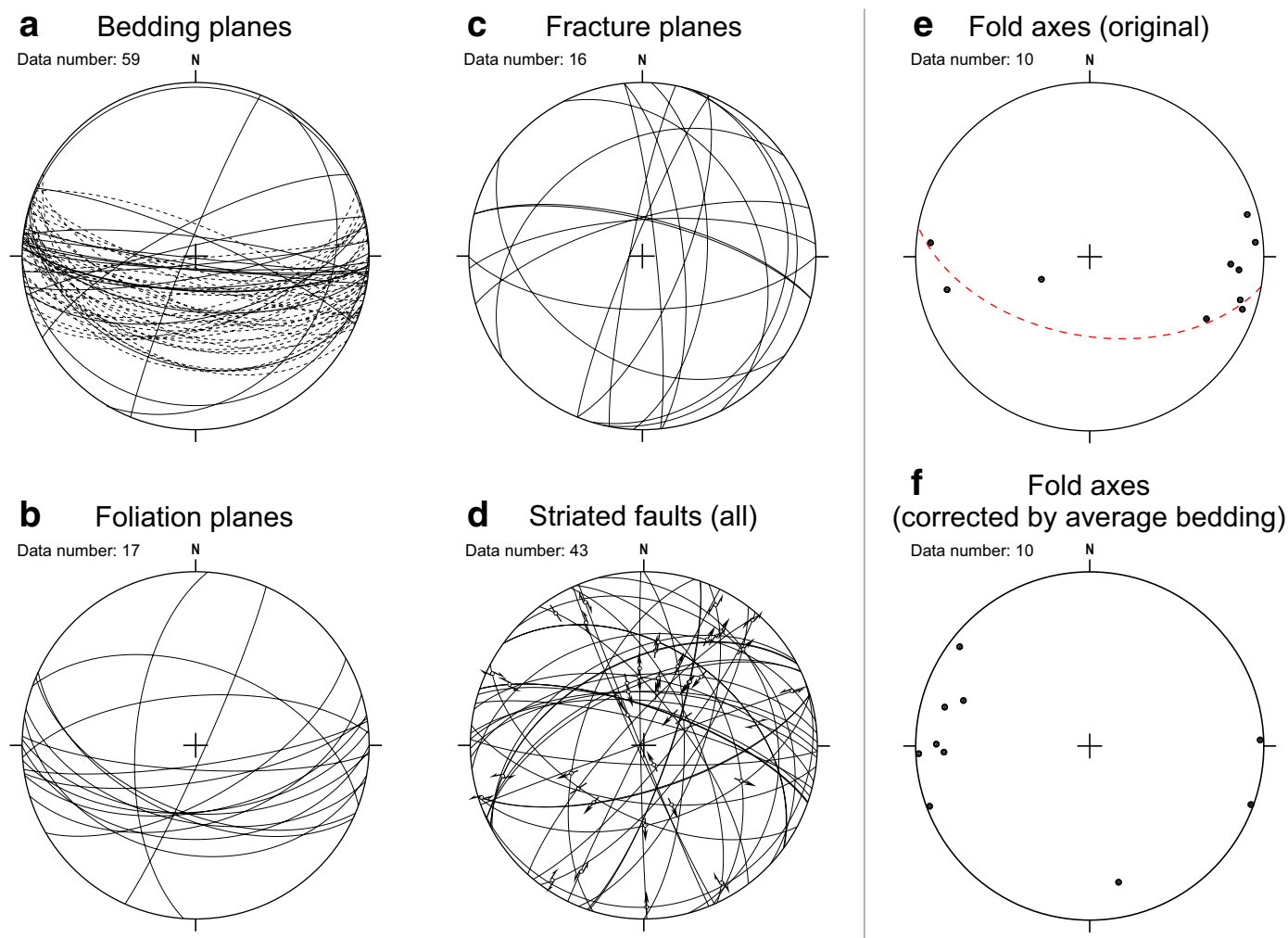

(corrected by average bedding)

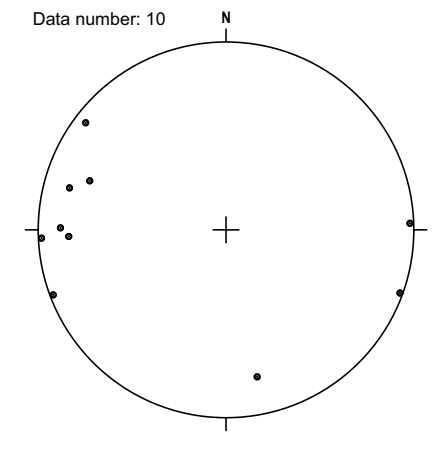

\section{g GSSP Striated fault (original)}

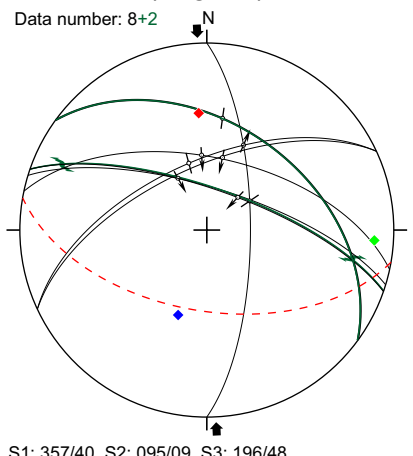

S1: $357 / 40$, S2: 095/09, S3: $196 / 48$
R: 0.312, R': 2.312, PURE COMPRESSIVE h GSSP Striated fault (corrected by average bedding)

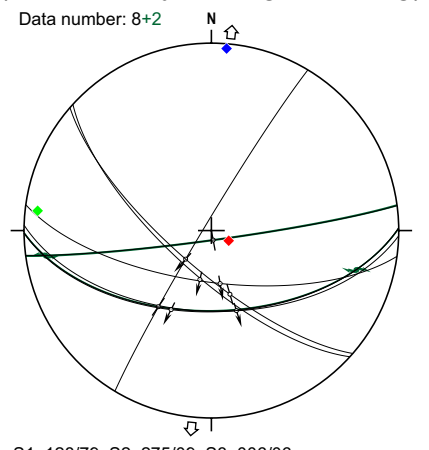

S1: $128 / 79$, S2: $275 / 09$, S3: 006/06
R: $0.312, R^{\prime}: 0.312$, PURE EXTENSIVE

\section{Legend}

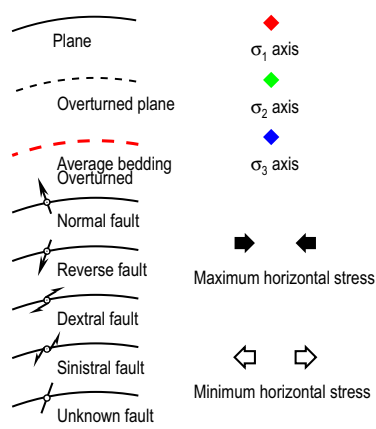

- Fold axis
Fig. 7 Stereograms of structural measurements and analyses at the Kuhjoch GSSP and in the Karwendel syncline, created using the SG2PS software (Schmidt net, lower hemisphere projection). a All bedding planes. Note the tight folding evident from similar dips on normal and overturned limbs. b All foliation planes. c All fracture and fault planes without observed striations. d All striated fault planes with striae shown as lineations. e All fold axes in their current position, mostly related to $\mathrm{N}-\mathrm{S}$ shortening. The average of all bedding planes is also shown. f All fold axes corrected by the average bedding to show the geometry preceding the regional folding. The overall setting is related to $\mathrm{N}-\mathrm{S}$ shortening, suggesting that the small- scale folds are parasites of the Karwendel syncline. $\mathbf{g}$ Measurements of striated faults at the Kössen-Kendlbach contact at the GSSP (Kuhjoch East and West) and at the location marked "Fig. 4f" in Fig. 6. Dip-slip faults are in black, strike-slip faults in green. The stress inversion was calculated according to Sprang (1972) only for the dipslip faults. Note the oblique stress field. The average of Kössen Formation bedding planes at the GSSP is also shown. $\mathbf{h}$ Correction of the GSSP faults in ' $\mathrm{g}$ ' by the average bedding to show the pre-folding geometry. The stress inversion according to Sprang (1972) was calculated only for the dip-slip faults, resulting in a simple extensional stress field 
Fig. 8 Characteristic deformation features in the Karwendel syncline. For location of individual images see Figs. 1 and 9. Bedding in orange, foliation and shear planes in green, faults in red, folds in blue. a Isoclinal, disharmonic folds in the Oberalm limestone. b Shear bands in the Schrambach limestone (top view). c Outcrop scale parasitic fold in the Schrambach limestone. The measured fold hinge is in accordance with the constructed fold axis (Schmidt net, lower hemisphere stereographic projection), indicative of north-south shortening. d Post-folding strike-slip fault in the Oberalm limestone. e Fault propagation fold in chert preceding or related to an early phase of folding. f Foliation exclusive exists in the incompetent marl intervals, without penetrating the limestone beds of the Scheibelberg Formation. Relative dips of bedding and foliation indicate an overturned setting. $\mathbf{g}$ Tight isopach folds in the Kössen limestone. $\mathbf{h}$ Pre-folding sinistral strike-slip fault now as an oblique normal fault in the Kössen limestone (Schmidt net, lower hemisphere stereographic projection)
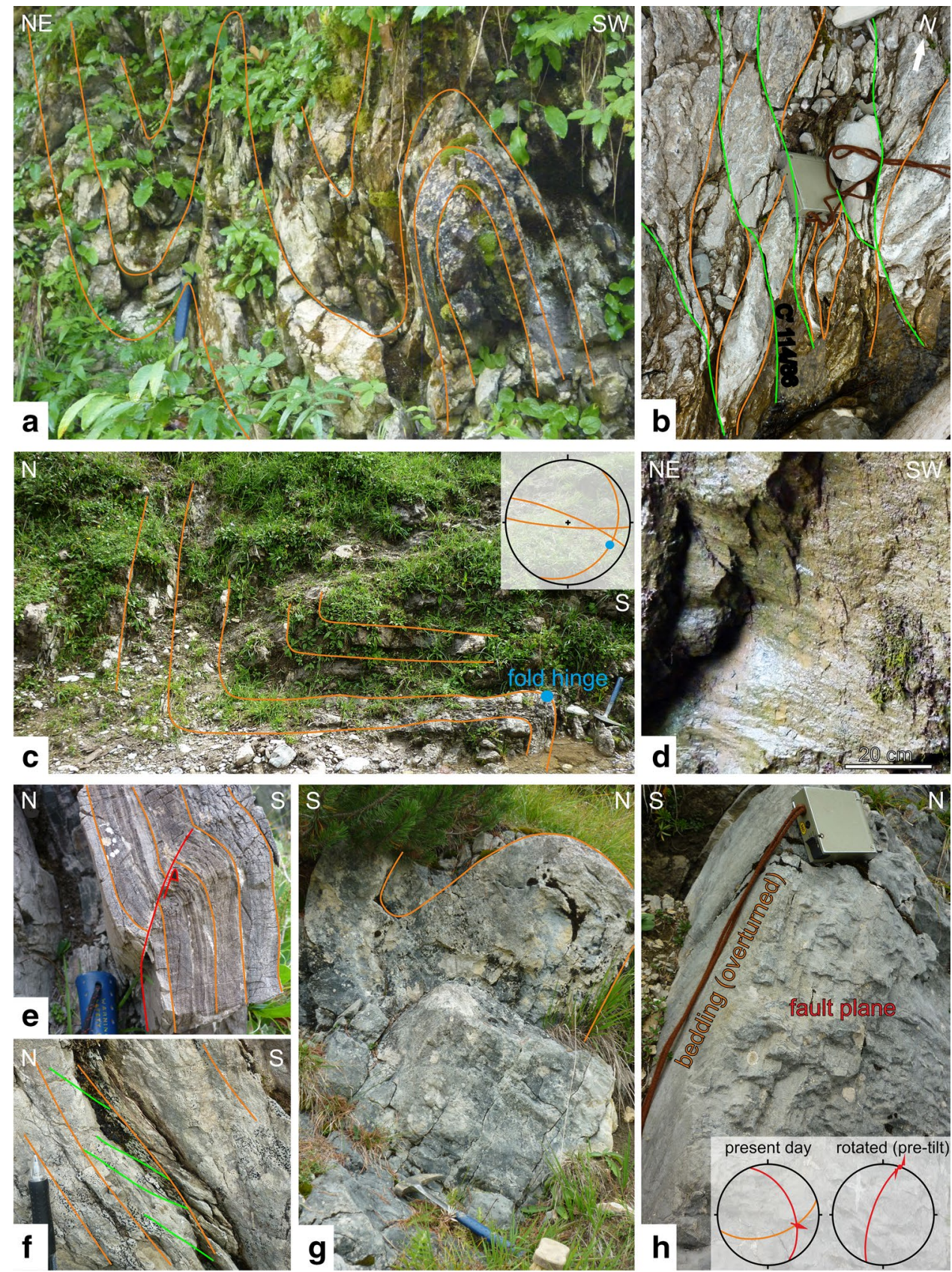

established, the geometry and asymmetry of these folds (Fig. 9) is in good agreement with the flexural slip folding mechanism (Tanner 1989), indicating they are parasites of a larger scale Karwendel syncline with northern vergency (Fig. 9).

Figure 8e shows a small-scale subvertical fault propagation fold. This semibrittle shortening structure with originally north-south orientation is most likely related to an early phase of folding. At several locations, semiductile extensional features such as shear bands (Fig. 8b) and asymmetric boudinage were observed.
Steep, often disjunctive foliation (Fig. 7b) with later sigmoidal deformation was identified in the incompetent marl and clay intervals of the section, but no similar features were observed in the competent sediments such as limestones and cherts (Fig. 8f). However, even the limestones have cleavage in zones suffering more intensive deformation.

The Kössen Formation has a number of tight, outcrop scale folds related to general north-south shortening as discussed above (Fig. 8g). Folds in this unit are less tight than in the Jurassic and Cretaceous succession, probably for 
Fig. 9 Cross section in the Karwendel syncline constructed from outcrop data. Inset shows the vicinity of the Kuhjoch saddle. For location see Fig. 1
$\mathrm{N}$

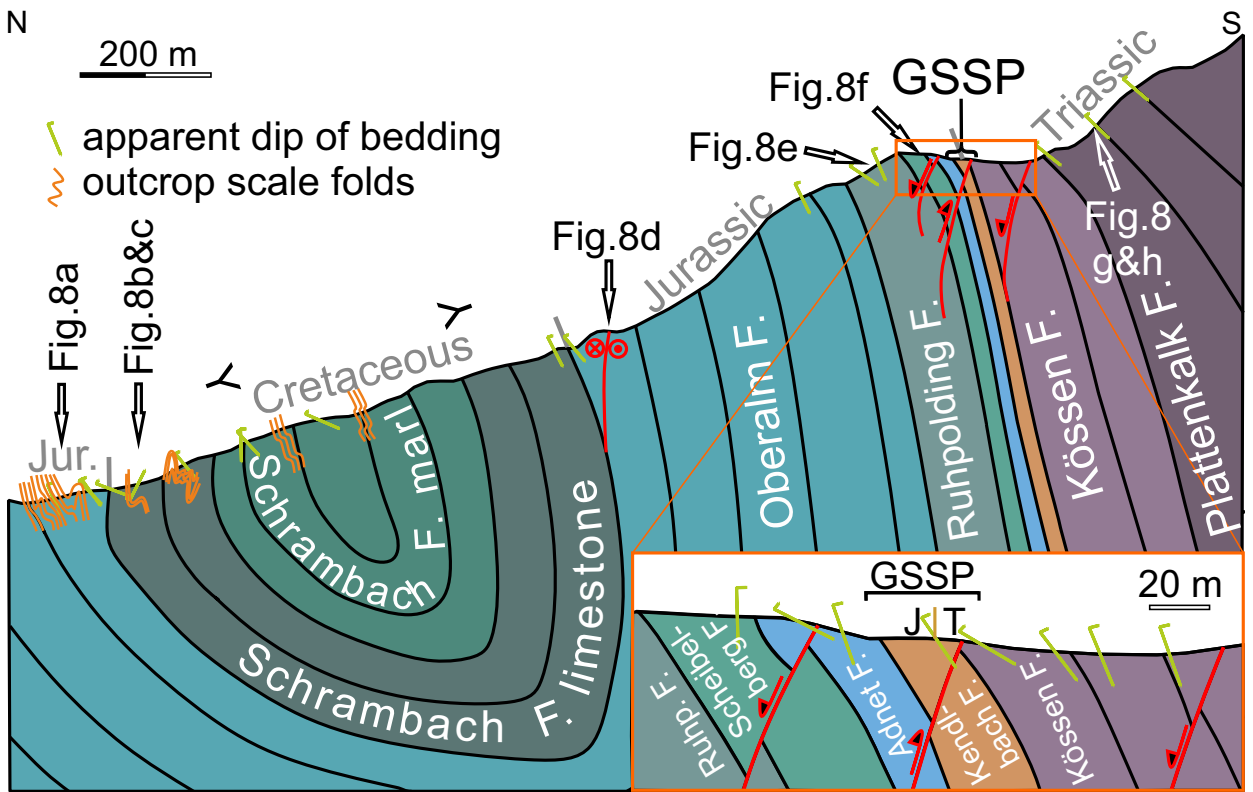

rheological reasons. Shale units of the Kössen Formation commonly show crenulations.

Brittle deformational features (Fig. 7c, d) are abundant in the southern part of the transect (Fig. 9). In the central part of the section, a well-developed set of strike-slip faults (Fig. 8d) was observed in the Oberalm limestone (Fig. 9). Fault zones in both the Lower Jurassic formations and the Kössen limestone were observed in the close proximity of the GSSP. The width of these fault zones is in the range of $10 \mathrm{~m}$ (Fig. 9). Because the detachment horizons of the faults could not be identified in the field, these were only schematically shown in the section (Fig. 9).

\section{Interpretation}

\section{Semibrittle deformation}

Semibrittle shortening resulted in tight or even isoclinal folding at various scales. The main shortening direction was north-south (Fig. 7e). Based on the asymmetry of outcrop scale folds and taking the general setting of the Karwendel syncline into account (Fig. 9), south to north tectonic transport directions can be inferred in accordance with the regional tectonic evolution (Linzer et al. 1995; Schmid et al. 2004; Tanner et al. 2003).

As the stereographic tilt test of fold axes (the rotation of fold axes by the average overturned bedding) did not significantly change the direction of folds (Fig. 7e, f), the observed outcrop scale folds are interpreted as parasites of the regional Karwendel fold train, in accordance with field observations.

\section{Ages of brittle faulting}

As the analysis of the whole, rather variable fault dataset (Fig. 7d) was beyond the scope of this study, stress inversion was carried out only for the striated faults at and close to the GSSP (at the Kuhjoch West and East trenches, as well as the natural outcrop east of Kuhjoch East, labelled Fig. 4f in Fig. 6). Due to the limited number of striae measurements, the methodology of Sprang (1972) was applied using the SG2PS software (Sasvári and Baharev 2014) (Fig. 7g, h). Only dip-slip faults were taken into consideration; strike-slip faults were not processed due to their limited number.

The dip angle of the reverse fault in the GSSP (Fig. 5) is unexpectedly high (Fig. 7g), suggesting an oblique stress field. Rotating the data by the average (overturned) bedding measured on the Kössen Formation at the GSSP site, a simple, kinematically valid extensional setting seems to be feasible (Fig. 7h). Therefore, we argue that the origin of the reverse fault at the GSSP site was an early, pre-folding normal fault that was related to crustal extension most likely during the Jurassic (cf. Gawlick et al. 2009). As an alternative, it could be related to local extension on the outer arc of an early-stage fold.

A similar conclusion on faulting prior to folding was arrived at on another outcrop in the Kössen Formation (Fig. 8h), where a current oblique normal fault was tilted back into a pre-folding strike-slip geometry. On the other hand, a number of faults (Figs. 7d, 8d) throughout the geological cross section are kinematically valid in their current position, suggesting their post-folding age.

Thus, brittle faulting occurred both before, after and most likely also during the Paleogene folding phase 
(Tanner et al. 2003) which produced the overturned Karwendel syncline.

\section{Discussion}

The summary paper of Hillebrandt et al. (2013) presented a synthesis of local stratigraphical and geological knowledge related to the Kuhjoch GSSP derived from a large number of earlier studies (Bonis et al. 2009, 2010; Hillebrandt and Krystyn 2009; Hillebrandt et al. 2007; Morton 2012; Ruhl et al. 2009, 2011); therefore, in the following discussion it is used as a key reference.

Hillebrandt et al. (2013) concluded that 'only minor tectonic overprint disrupts the sedimentary sequence'. Their Table 1 contains a somewhat contradictory statement that tectonic disturbances near the boundary level were absent. In the following, three topics regarding the definition and suitability of GSSP will be discussed and clarified: (1) the definition of stratigraphic distances and the distinction of bedding and foliation, (2) faults in the GSSP, and (3) the regional tectonic overprint.

\section{Difficulties of measuring stratigraphic distance and the definition of bedding and foliation}

The measurement method used within the sections is not detailed by Hillebrandt et al. (2013) who only stated the distances in metres. Congruence of stratigraphic columns as well as the data in the text suggests that distances are given as stratigraphic thickness rather than apparent, horizontal distance without the correction of the observed dips. However, the measurement of stratigraphic thickness perpendicular to bedding is challenging as the distinction of bedding and foliation is ambiguous at the GSSP site (Fig. 4a, b), and dips also change in space (Fig. 6). Because bedding data were not indicated and the presence of foliation was not discussed by Hillebrandt et al. (2013), it cannot be ruled out that foliation was mixed up with the bedding. Eventually, the bedding of the Kössen Formation in the footwall of the east-west striking reverse fault might have been taken by Hillebrandt et al. (2013) to represent bedding along the whole section, i.e. also in the hanging wall. A dip change from $190 / 85$ to $175 / 58$ (representative bedding and foliation data, respectively, from Kuhjoch East; Fig. 4b) would change the horizontally measured apparent thickness of a 5.8-m-thick layer [i.e. the distance between the Kössen-Kendlbach boundary and the Golden Spike according to Hillebrandt et al. (2013)] by $1.0 \mathrm{~m}$. Reproducibility of stratigraphic results is hampered by this ambiguity.

\section{Faults at the GSSP}

There are several problems at the GSSP regarding the presence or absence of faults. Because a continuous sedimentary succession is needed to fulfil the GSSP requirements, this issue is regarded to be critical.

At Kuhjoch East, Hillebrandt et al. (2013) labelled a fault in their subsection 2D on their Fig. 9 (location in Fig. 3a and their Fig. 8), but paradoxically stated that 'an undisturbed transition from the Eiberg Member (of the Kössen Formation) to the Tiefengraben Member' exists in their subsection $2 \mathrm{E}$, only $1-2 \mathrm{~m}$ from subsection $2 \mathrm{D}$ (Fig. 3a and their Fig. 8). According to our observations, the east-west striking reverse fault is well represented in both the 2D and the 2E subsections (Fig. 3a, b). In subsection $2 \mathrm{E}$, the fault runs within the Schattwald Beds, and juxtaposes two incomplete Schattwald successions. In subsection 2D, the fault juxtaposes the limestones of the Kössen Formation to the Schattwald Beds, implying the tectonic omission of the base of the Schattwald Beds (Fig. 3c). The minimum reverse offset on the fault is 2-3 m ("Structural observations at the GSSP site").

The 'small local fault' (Hillebrandt et al. 2013) in the upper part of the Schattwald Beds at Kuhjoch West revealed by a shift in carbon isotopes (Bonis et al. 2009), and also by a missing assemblage zone in the palynological record, at a "10-20-cm-thick and tectonically deformed clay horizon" (Hillebrandt et al. 2013), was not discovered in the field. However, there is a substantial fault between the Kössen Formation and the Tiefengraben Member in the Kuhjoch West section (Fig. 5a), which was not identified by Hillebrandt et al. (2013) (cf. Fig. 5a with their Fig. 7). The basal beds of the Tiefengraben Member could be excavated below the overturned Kössen limestone in the footwall position, but there is no stratigraphic continuity towards the northern part of the trench where the Tiefengraben Member and other units with stratigraphically higher position are exposed in a hanging wall position. Because the offset along the fault can only be estimated ("Structural observations at the GSSP site"), the amount of tectonic hiatus in the section cannot be precisely established. Matching the stratigraphical thicknesses between Kuhjoch West, the originally proposed GSSP (Hillebrandt et al. 2007), and Kuhjoch East, the eventual GSSP with the 'Golden Spike' (Hillebrandt et al. 2013; Morton 2012), is problematic because of the faulted contact between the Kössen and Kendlbach formations in Kuhjoch East.

According to the field observations, there is no single continuous section from the Kössen Formation to the top of the Schattwald Beds in the Kuhjoch sections, as both the eastern and the western trench successions are disturbed by a fault with at least 2-3 m reverse offset (Fig. 3b, c) in its current position (Fig. 7g). Offset along this fault resulted in 
the tectonic omission of the base, or near-basal parts, of the Schattwald Beds (Fig. 3c). This observation conflicts with the requirement of the International Committee on Stratigraphy for GSSPs to be free of tectonic disturbances near the boundary level.

\section{Regional tectonic overprint}

The 'small shear zone' or 'minor fault' (Hillebrandt et al. 2013) at the top of the Schattwald Beds at Kuhjoch West, the faults discussed in "Faults at the GSSP", and the existence of foliation in the Kendlbach Formation (Fig. 4a, b) are direct evidence of tectonic disturbance at the GSSP site. Taking the observations in the wider surroundings (Figs. 8, 9) into account, significant deformation was detected in the overturned Karwendel syncline as well. Due to the extreme rheological weakness of the clay succession at the Triassic-Jurassic boundary it is expected to be even more deformed than the overlying and underlying competent carbonates. Because carbonates are heavily folded and faulted even very close to the GSSP, there is high risk that the Kendlbach Formation is sheared to a higher extent than currently observed.

\section{Conclusions}

1. The almost isoclinal, overturned, gently inclined Karwendel syncline was formed at semibrittle conditions. Tight to isoclinal parasitic folds indicate flexural slip folding.

2. Incompetent formations are foliated even at the GSSP sections, where the 'Golden Spike' was installed in the clay-rich sequence of the Kendlbach Formation. Foliation is axial planar to the Karwendel syncline.

3. Brittle faulting occurred both before and after folding, as confirmed by tilting tests.

4. A reverse fault with a minimum 2-3 m offset separates the Kössen Formation and the Kendlbach formations in the GSSP sections. Although a continuous succession from the top of the Kössen Formation to the lowermost Schattwald Beds was observed in the footwall, the presence of the reverse fault makes the compilation of a continuous stratigraphic section of the Kendlbach Formation impossible. The true stratigraphic thickness of the Schattwald Beds at Kuhjoch is inferred to be minimum 4-5 $\mathrm{m}$, with the basal parts of this missing due to offset along the reverse fault.

5. The reverse fault in the GSSP sections was probably formed as a normal fault before or during the early phase of folding and became tilted and overturned during the formation of the syncline. The reverse fault is crosscut by a later north-south striking fault that runs between the Kuhjoch East and West sections.

6. The presence of a fault with significant offset near the boundary level raises questions about the suitability of the Kuhjoch section as a GSSP, for it does not satisfy the explicit requirement of absence of tectonic disturbances.

Acknowledgements The authors appreciate the field support of Norbert Zajzon, and the technical help of Magdalena Biszczuk. Axel von Hillebrandt is thanked for providing access to an unpublished thesis. This study was supported by the Hungarian Scientific Research Fund (OTKA) Grant K72633. This paper benefited from the thorough reviews of Stephen Hesselbo and an anonymous reviewer. This is Cambridge Earth Sciences contribution number ESC.3793 and MTAMTM-ELTE Paleo contribution number 228.

Open Access This article is distributed under the terms of the Creative Commons Attribution 4.0 International License (http:// creativecommons.org/licenses/by/4.0/), which permits unrestricted use, distribution, and reproduction in any medium, provided you give appropriate credit to the original author(s) and the source, provide a link to the Creative Commons license, and indicate if changes were made.

\section{References}

Bonis NR, Kurschner WM, Krystyn L (2009) A detailed palynological study of the Triassic-Jurassic transition in key sections of the Eiberg Basin (Northern Calcareous Alps, Austria). Rev Palaeobot Palynol 156:376-400. doi:10.1016/j.revpalbo.2009.04.003

Bonis NR, Ruhl M, Kurschner WM (2010) Climate change driven black shale deposition during the end-Triassic in the western Tethys. Palaeogeogr Palaeoclimatol Palaeoecol 290:151-159

Eisbacher G, Brandner R (1996) Superposed fold-thrust structures and high-angle faults, Northwestern Calcareous Alps, Austria. Eclogae Geol Helv 89:553-571

Furrer H (1993) Stratigraphie und Facies der Trias/Jura-Grenzschichten in den Oberostalpinen Decken Graubündens. ETH Zürich

Gawlick H-J, Krystyn L, Lein R (1994) Conodont colour alteration indices: Palaeotemperatures and metamorphism in the Northern Calcareous Alps-a general view. Geol Rundsch 83:660-664. doi:10.1007/bf01083235

Gawlick H-J et al (2009) Jurassic Tectonostratigraphy of the Austroalpine domain. J Alp Geol 50:1-152

Hillebrandt AV, Krystyn L (2009) On the oldest Jurassic ammonites of Europe (Northern Calcareous Alps, Austria) and their global significance. Neues Jahrbuch für Geologie und Paläontologie Abhandlungen 253:163-195

Hillebrandt AV, Krystyn L, Kuerschner WM (2007) A candidate GSSP for the base of the Jurassic in the Northern Calcareous Alps (Kuhjoch section, Karwendel Mountains, Tyrol, Austria). Int Subcomm Jurass Stratigr News1 34:2-20

Hillebrandt AV et al (2013) The global stratotype sections and point (GSSP) for the base of the Jurassic System at Kuhjoch (Karwendel Mountains, Northern Calcareous Alps, Tyrol, Austria). Episodes 36:162-198

Köhler M (1986) Leermoser Tunnel (Ausserfern, Tirol). Baugeologische Verhältnisse, Prognose und tektonische Slussfolgerungen. Geologische und Paläontologische Mitteilungen. Innsbruck 13:363-379 
Kralik M, Krumm H, Schramm J (1987) Low grade and very low grade metamorphism in the Northern Calcareous Alps and in the Greywacke Zone: Illite-crystallinity data and isotopic ages. In: Flügel HW, Faupl P (eds) Geodynamics of the Eastern Alps, vol 178. Deuticke, Vienna, pp 164-178

Krische O, Bujtor L, Gawlick H-J (2013) Calpionellid and ammonite biostratigraphy of uppermost Jurassic to Lower Cretaceous sedimentary rocks from the Leube quarry (Northern Calcareous Alps, Salzburg, Austria). Aust J Earth Sci 106:26-45

Krystyn L, Böhm F, Kuerschner WM, Delecat S (2005) The Triassic-Jurassic boundary in the Northern Calcareous Alps. In: Pálfy J, Ozsvárt P (eds) Program, Abstracts and Field Guide. 5th Field Workshop of IGCP 458 Project. Tata and Hallein, pp A1-A14

Kuerschner WM, Bonis NR, Krystyn L (2007) Carbon-isotope stratigraphy and palynostratigraphy of the Triassic-Jurassic transition in the Tiefengraben section-Northern Calcareous Alps (Austria). Palaeogeogr Palaeoclimatol Palaeoecol 244:257-280

Linzer H-G, Ratschbacher L, Frisch W (1995) Transpressional collision structures in the upper crust: the fold-thrust belt of the Northern Calcareous Alps. Tectonophysics 242:41-61. doi:10.1016/0040-1951(94)00152-y

Mette W et al. (2016) Field trip 11: Rhaetian (Late Triassic) biotic and carbon isotope events and intraplatform basin development in the Northern Calcareous Alps, Tyrol, Austria. GeoAlp 12:1-24

Morton N (2012) Inauguration of the GSSP for the Jurassic System. Episodes 35:328-332

Moser M (2008) Geofast-Zusammenstellung ausgewählter Archivunterlagen der Geologischen Bundesanstalt. Innsbruck 1:50.000-118

Piller WE, Erhart CW (2004) Die stratigraphische Tabelle von Österreich 2004 (sedimentare Schichtfolgen). Komission für die paleontologische und stratigraphische Erforschung Österreichs der Österreichischen Akademie der Wissenschaften und Österreichische Stratigraphische Komission

Remane J (2003) Chronostratigraphic correlations: their importance for the definition of geochronologic units.
Palaeogeogr Palaeoclimatol Palaeoecol 196:7-18. doi:10.1016/ s0031-0182(03)00310-9

Richoz S, Krystyn L (2015) The Upper Triassic events recorded in platform and basin of the Austrian Alps. Triassic/Jurassic GSSP Norian/Rhaetian GSSP Candidate. Berichte der Geologischen Bundesanstalt 111:75-136

Ruhl M, Kuerschner WM, Krystyn L (2009) Triassic-Jurassic organic carbon isotope stratigraphy of key sections in the western Tethys realm (Austria). Earth Planet Sci Lett 281:169-187

Ruhl M, Bonis NR, Reichart GJ, Damste JSS, Kurschner WM (2011) Atmospheric carbon injection linked to end-Triassic mass extinction. Science 333:430-434 doi:10.1126/science.1204255

Sasvári Á, Baharev A (2014) SG2PS (structural geology to postscript converter)-A graphical solution for brittle structural data evaluation and paleostress calculation. Comput Geosci 66:81-93 doi:10.1016/j.cageo.2013.12.010

Schmid SM, Fügenschuh B, Kissling E, Schuster R (2004) Tectonic map and overall architecture of the Alpine orogen. Eclogae Geol Helv 97:93-117

Schütz S (1974) Die Geologie der Karwendel-Mulde zwischen Dürrach und Baumgartenjoch (Nordtirol). Diploma Thesis. Technical University, Berlin

Sprang JH (1972) Numerical method for dynamic analysis of calcite twin lamellae. Geol Soc Am Bull 83:467

Tanner PWG (1989) The flexural-slip mechanism. J Struct Geol 11:635-655

Tanner DC, Behrmann JH, Dresmann H (2003) Three-dimensional retro-deformation of the Lechtal Nappe, northern Calcareous Alps. J Struct Geol 25:737-748

Tollmann A (1976a) Analyse des klassischen nordalpinen Mesozoikums: Stratigraphie, Fauna und Fazies der nördlichen Kalkalpen. Deuticke, Vienna

Tollmann A (1976b) Der Bau der nördlichen Kalkalpen. Deuticke, Vienna 